Prizes

\section{US winners for Israeli prizes}

Rehovot

US CITIZENS walked off with most of this year's Wolf Prizes, just as they did with most of the Nobel Prizes (although the prize categories are not identical).

In mathematics, for example, the $\$ 100,000$ Israel-based international award went to a pair of European-born Americans, Professor Samuel Eilenberg of Columbia University and Professor Alte Selberg of the Institute for Advanced Study at Princeton. Eilenberg was chosen for his fundamental work in algebraic topology and homological algebra, while Selberg was honoured for his profound and original work on number theory and on discrete groups and automorphic forms.

Opening up a new field of research, the study of chaos won Wolf Prizes in Physics for an American, Professor Mitchell Jay Feigenbaum of Cornell University, and a Frenchman working in the United States, Professor Albert Joseph Libchaber of the University of Chicago.

Professor Elias James Corey of Harvard University and Professor Albert Eschenmoser of the Swiss Federal Institute of Technology (ETH) share the Wolf Prize in Chemistry, in recognition of their research on the synthesis, stereochemistry and reaction mechanisms for the formation of complex natural products, particularly vitamin $\mathbf{B}_{12}$. Eschenmoser is the first Swiss national to receive a Wolf Prize.

In agriculture, the prize is shared by $\mathrm{Dr}$ Ernest R.R. Sears of the Unversity of Missouri and Sir Ralph Riley of the UK Agricultural and Food Research Council. The two cytogeneticists were cited for their independent research in basic plant breeding, which has permitted the insertion into wheat of genes representing desirable characteristics from alien plants so as to improve wheat germ plasms and cultivars.

The Wolf Prize in Medicine, the last to be announced, went this year to a Japanese researcher, Professor Oshmu Hayaishi, president of the Osaka Medical College, for his discovery of oxygenases, a group of enzymes that are catalysts in the use of oxygen by living organisms. They also, as the citation noted, play a crucial role in the metabolic disposal of foreign compounds such as drugs and insecticides.

The Wolf Foundation, which has been awarding annual prizes since 1978 , was established by the late Dr Ricardo Wolf, a German-born chemist and philanthropist who lived for many years in Cuba. Appointed Cuban Ambassador to Israel in the 1960 s by his friend Fidel Castro, he remained in Israel after Cuba broke off diplomatic relations in 1967 until his death in 1981.

Nechemia Meyers

US science and technology

McTeague looks to the future

\section{Washington}

CONTEMPlating the future of your agency when it is faced with a 28 per cent budget cut is not a cheerful prospect. But that is the plight of John McTeague in his first weeks as acting director of the White House Office of Science and Technology Policy (OSTP). "We can operate with a budget at almost any level, the question is which activities the office will undertake", says McTeague. "That is a matter of consideration by the Congress."

Last month McTeague was on Capitol Hill before a Senate appropriations subcommittee. While he did not appeal for more money for his agency, McTeague did say that he would be very happy with a 10 per cent cut in his budget, considering the alternative he is faced with.

McTeague is not behaving like a temporary incumbent marking time while waiting to be replaced. Before the congressional committee he was quick to point out the need for a stronger hand in guiding science and technology policy by the federal government. He plans to provide some of that guidance through his own role as chairman of the dozen committees making up the Federal Coordinating Council on Science, Engineering and Technology (FCCSET). While he refuses to state explicitly that he favours a cabinet level department, he clearly feels the present system is awkward.

McTeague considers that most people fail to appreciate the scope of OSTP's activities. "OSTP is a little like an impressionist painting", said McTeague. "If you don't stand back, you miss the picture."

One FCCSET committee, formed last December, is attempting to place renewed emphasis on international cooperative agreements in which the United States is involved.

"It's not an effort to dictate individual programmes", says McTeague. But this does not mean that OSTP will support US participation in international programmes that do not fall in line with domestic priorities or international policies. McTeague believes that the most effective international interactions are those that take place informally, with government maintaining a hands-off policy.

One project with enormous international implications is the proposed Superconducting Supercollider (SSC). With a price tag approaching $\$ 6,000$ million, there is a natural reluctance to forge ahead, although McTeague maintains that the present administration firmly supports high-energy physics.

"We have to take a good hard look at it [SSC] and see how it fits in at this time with national priorities and budget exigencies", says McTeague. Although greater cooperation with the European Organisation for Nuclear Research (CERN) may be a practical alternative to building SSC, it seems to fly in the face of a strong commitment by the government to maintaining "this nation's forefront role in high-energy physics"

OSTP has also recently become embroiled in the question of how to proceed with the US space programme following the shuttle disaster. The administration is faced with an expensive problem of whether to buy a new shuttle orbiter in a year when budgets are austere all round. While the administration has not yet officially made a decision, McTeague says expanded use of expendable rocket launch vehicles will provide a solution only "in the short run".

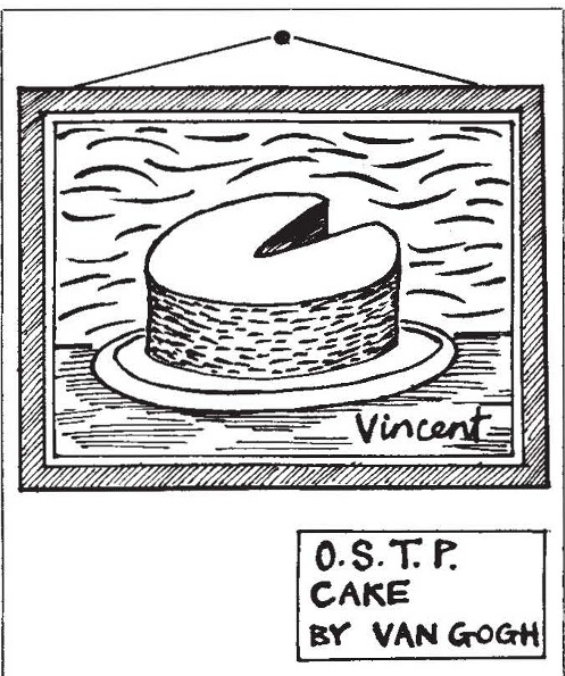

McTeague feels that the most effective federal role in science and technology "is not to attempt to drive specific commercial technologies, but to support forefront basic research, which will have payoffs not foreseeable at the time of funding". At the same time, he supports "problem focused" science centres at universities, aimed at areas of "broad national needs and relevant to industrial technology". McTeague explains this apparent contradiction by pointing out that it will be scientists, not the government, who will identify these "problems". The government's role will be to nurture these centres once their direction has been plotted.

McTeague has had three years in Washington to watch and participate in the workings of OSTP. He clearly intends to continue pressing for federal support of science, although he is anxious that industry should contribute its share to the financial burden. With the GrammRudman cloud hanging over the United States and the federal budget, running OSTP will not be an easy job. Perhaps it never is. 